\title{
Photosynthetic capacity of three phytoplanktonic species measured by a pulse amplitude fluorometric method
}

\author{
Cleber C. Figueredo ${ }^{1}$, Alessandra Giani ${ }^{*}$ and José P. Lemos Filho ${ }^{1}$.
}

\footnotetext{
${ }^{1}$ Departamento de Botânica, Instituto de Ciências Biológicas, Universidade Federal de Minas Gerais, P0 Box 486, 31270-010 Belo Horizonte, MG, Brazil.
}

*Corresponding author: agiani@icb.ufmg.br. Received: 04 April 2009; Accepted: 22 October 2009.

\begin{abstract}
During photosynthesis, absorbed energy that is not used in photochemical reactions dissipates as fluorescence. Fluorescence provides important information on the physiological conditions of the studied organisms and its measurement is widely used by plant physiologists and can be valuable in phytoplankton studies. We describe a method adapting a plant fluorometric equipment to measure the photosynthetic capacity of microalgae. Unialgal cultures of three planktonic chlorophytes were exposed to 3(3,4dichlorophenyl)-1,1-dimethylurea (DCMU), an inhibitor of photosystem II, at concentrations of $0.1,1.0$ and $10.0 \mu$ mol. $^{-1}$. Estimates were made of photosynthetic parameters, including operational and potential photosystem II quantum yield and electron transport rate between photosystems, using algal cells concentrated on glass-fiber filters. The technique allowed reliable measurements of fluorescence, and detection of distinct levels of inhibition. Physiological or morphological characteristics of the selected species might provide an explanation for the observed results: differences on the surface/volume ratio of the cells and colony morphology, for example, were associated with contrasting resistance to the toxicant. To characterize inhibition on phytoplanktonic photosynthesis, we suggest operational quantum yield and electron transport rate as best parameters, once they were more sensitive to the DCMU toxicity.
\end{abstract}

Key words: chlorophytes photosynthesis, Electron Transport Rate, phytoplankton.

\section{RESUMO}

Durante os eventos fotossintéticos, a energia absorvida que não é usada em reações fotoquímicas pode ser dissipada como fluorescência. Sua medida fornece importantes informações acerca das condições fisiológicas dos organismos, sendo amplamente utilizada na fisiologia vegetal e podendo ser valiosa nos estudos do fitoplâncton. Este estudo descreve um método no qual um equipamento elaborado para a realização de medidas de fluorescência em plantas é utilizado para medir a capacidade fotossintética de microalgas. Culturas unialgais de três clorófitas planctônicas foram expostas a três concentrações de 3(3,4-diclorofenil)-1,1dimetiluréia (DCMU), um inibidor do fotossistema II. Foram quantificados alguns parâmetros fotossintéticos, como os rendimentos quânticos efetivo e potencial do fotossistema II e a taxa de transporte de elétrons entre os fotossistemas. Para tal, as células algais foram concentradas em filtros de fibra de vidro. Esta técnica permitiu a quantificação da fluorescência proveniente do aparato fotossintético destas microalgas, possibilitando a detecção de diferentes níveis de inibição, segundo a espécie. Características fisiológicas ou morfológicas das espécies poderiam justificar os resultados observados: diferenças na razão superfície/volume das células e na forma das colônias, por exemplo, foram associadas aos níveis distintos de resistência ao DCMU. Para a avaliação da 
inibição da fotossíntese fitoplanctônica, nós sugerimos o rendimento quântico efetivo e a taxa de transporte de elétrons como os parâmetros mais adequados, uma vez que foram os mais sensíveis à toxicidade do DCMU.

Palavras-chave: fotossíntese em clorófitas, taxa de transporte de elétrons, microfitoplâncton.

\section{INTRODUCTION}

When the photosynthetic apparatus absorbs more light energy than can be used for photochemical conversions, the excessive excitation energy has to be dissipated to maintain normal physiological cell conditions. The dissipation of nonphotochemical energy occurs as heat and fluorescence (Schreiber, 2003). Fluorescence is mainly emitted by the photosystem II (PSII) associated chlorophyll a, and it is a measure of its photosynthetic capacity and physiological conditions (Schreiber, 2003).

Fluorescence parameters are a rapid, sensitive, noninvasive and non-destructive methodology (Schreiber et al., 1995; Juneau and Popovic, 1999) for physiological studies. They allow the assessment of different factors on photosynthesis, at concentration lower than that affecting growth rates (Macedo et al., 2008), and a more specific evaluation of one photosystem, since fluorescence is mainly linked to PSII (Dorigo and Leboulanger, 2001).

Several methods to assess chlorophyll a fluorescence were developed and employed in plant research (Schreiber and Bilger, 1987). Among different fluorescence techniques, the pulse amplitude modulation (PAM) fluorometry is widely used today. This method operates with three kinds of light, modulated, actinic, and saturating, which allow the analyses of fluorescence-induction kinetics in plants and the evaluation of their primary productivity (see Schreiber, 1986, for detailed discussion). Important parameters for the evaluation of the photosynthetic metabolic state (Schreiber, 1986) can be quantified, such as the potential PSII quantum yield (represented as $\Phi_{\mathrm{M}}$ or Fv/Fm), the operational PSIl quantum yield (represented as $\Phi_{M}^{\prime}$ or $\Delta F / F{ }^{\prime} m$ ), and the electron transport rate (ETR) between PSII and PSI.

However, PAM fluorometry is not yet widely used in phytoplankton studies, although it clearly opens new research opportunities in aquatic ecology. Lu and Vonshak (1999), for example, investigated several characteristics of the PSII photochemistry and evaluated the use of different fluorescence parameters as indicators for photoinhibition in outdoor cyanobacterial cultures. Parkhill et al. (2001) measured the efficiency and sensitivity of PAM fluorometry to study the effects of nutrient stress on phytoplankton potential quantum yield. Villareal (2004) used a PAM system to study the photosynthetic responses of the giant diatom Ethmodiscus, in comparison with co-occurring species and bulk phytoplankton. However, even if PAM fluorometry can show a great potential to evaluate environmental conditions or to study new aspects of phytoplankton ecophysiology, species particularities or different culture conditions have shown to affect the final results (Nash and Quayle, 2007), therefore the technique has to be used very accurately.

The present work aims to present a simple methodology, which adapt a PAM equipment, routinely used for terrestrial plant (Mini-PAM, Waltz, Germany), to obtain useful and reliable measurements of the photosynthetic capacity of different phytoplanktonic species. Measurements of absolute values of photosynthetic parameters in phytoplankton are not completely understood (Wilhelm et al., 2004) and its discussion is beyond the scope of the present study. The purpose of this research was to estimate algal speciesspecific susceptibility to a toxicant, through relative values. Our goal was also to evaluate if variations in fluorescence parameters could be precisely detected by Mini-PAM and, thus, if the equipment would be an useful tool for algal ecophysiological studies. Finally, we also intended to suggest the best parameter to detect inhibitory effects on PSIl of phytoplankton, based on measurements performed on light- $\left(\Phi_{M}\right)$ and dark-adapted algae $\left(\Phi_{M}^{\prime}\right.$ and ETR).

\section{MATERIALS AND METHODS}

Fluorescence methodology (a short review): The operational (effective) PSIl quantum yield $\left(\Phi_{M}^{\prime}\right)$ corresponds to the effective plant capacity to convert light energy into chemical energy. To measure $\Phi^{\prime}$, samples are maintained under ambient light conditions, when $Q_{A}$ (quinone $A$, the first electron acceptor of the chain between PSII and PSI) is partly reduced according the light level. A basal fluorescence level 
$\left(F^{\prime}\right)$ is recorded and a very intense saturation pulse (SP) is applied on the sample. This pulse leads to a complete closure of PSII (i.e. full reduction of $Q_{A}$ ). At this moment, additional energy captured in PSII cannot be used in photochemistry and is emitted as a maximal fluorescence $F_{m}{ }_{m}$. With $F^{\prime}$ and $F_{m}$ values, we can calculate the effective PSII quantum yield as:

$$
\Phi_{M}^{\prime}=\left(\Delta F / F_{m}^{\prime}\right)=\left(F_{m}^{\prime}-F^{\prime}\right) / F_{m}^{\prime}
$$

The measurements can be made under increasing actinic light levels to obtain a curve of $\Phi_{\mathrm{M}}^{\prime}$. Changes of the minimal $\left(F^{\prime}\right)$ and maximal $\left(F_{m}^{\prime}\right)$ fluorescence yield are recorded for these light intensities by SPs given periodically. Such curve provides a notion of the current status of light adaptation to the ambient light conditions (Schreiber et al., 1997). The relative photosynthetic electron transport rate (ETR) between PSII and PSI can be calculated as the multiplication of $\Phi^{\prime}{ }_{M}$ with the corresponding light intensity of photosynthetically active radiation (PAR) (Genty et al., 1989; Wilhelm et al., 2004):

$$
\mathrm{ETR}=\Phi_{\mathrm{M}}^{\prime} \cdot \operatorname{PAR} \cdot 0.5
$$

The 0.5 factor is often used in the literature because only about $50 \%$ of the absorbed quanta are distributed to the photosystem II (PSII) (Schreiber et al., 1995). The other 50\% fraction is directly absorbed by the photosystem I (PSI).

Measurements of the potential quantum yield are taken in dark conditions, when all PSII reaction centers are open, and the minimal fluorescence, $F_{0}$, emitted mainly from antenna pigments (Krause and Weis, 1991), is measured. After the recording of $F_{0}$, a very intense pulse of light is emitted that saturates the reaction centers, suppressing the photochemical quenching (Schreiber, 1986). Under this condition, the excessive excitation of chlorophyll pigments must be dissipated, and a maximum fluorescence value, $F_{m}$, is recorded. Using these measurements, we can calculate the potential quantum yield as:

$$
\Phi_{\mathrm{M}}=\left(\mathrm{F}_{\mathrm{v}} / \mathrm{F}_{\mathrm{m}}\right)=\left(\mathrm{F}_{\mathrm{m}}-\mathrm{F}_{0}\right) / \mathrm{F}_{\mathrm{m}}
$$

Algal strains: Water samples were collected by a Van Dorn sampler in a central station in Lagoa Santa lake (Minas Gerais, Brazil) between August 2003 and August 2004. Strains of several phytoplanktonic species were isolated and are maintained in batch culture conditions at the Phycology Laboratory of the Federal University of Minas Gerais. Clonal non-axenic cultures were established using microcapillary pipettes for isolation of individual cell, trichome or colonie under an optical microscope. Cultures were grown in Erlenmeyer flasks at $22 \pm 1^{\circ} \mathrm{C}$, under $110 \mu \mathrm{mol}$ photon $\cdot \mathrm{m}^{-2} \cdot \mathrm{s}^{-1}$ provided by cool-white fluorescent lamps at a light-dark cycle of 12:12 h. Isolation and growth of cultures were performed in WC medium (Guillard and Lorenzen, 1972).

Experiments: Three chlorophyte cultures (Tetrallantos lagerheimii Teiling, Coelastrum sphaericum Naegeli and Pediastrum boryanum (Turpin) Meneghini) at exponential growth were chosen as the targetfor PSIl inhibition experiments. The culture densities at the start of the experiments were $2.2 \cdot 10^{6}, 5.9 \cdot 10^{6}$ and $1.1 \cdot 10^{6}$ cell.mL $\mathrm{mL}^{-1}$, respectively, for Tetrallantos lagerheimii, Coelastrum sphaericum and Pediastrum boryanum. Biovolume and superficial area of each species were obtained by stereometric calculations according to Rott (1981) and the surface:volume (S:V) ratios were calculated.

The experiments were performed by fractioning a single target culture in 12 erlenmeyers flasks ( $125 \mathrm{~mL}$ capacity). All treatments were performed in triplicate and each flask received $19.8 \mathrm{~mL}$ of the cultures. We conducted the inhibition experiments by exposing the species at exponential growth to different concentrations of the herbicide DCMU $(3(3,4-$ dichlorophenyl)-1,1-dimethylurea), a specific inhibitor of PSII. For this purpose, control Erlenmeyer flasks received 0.2 $\mathrm{mL}$ of distilled water and the treatments received the same volume of DCMU at different concentration, producing a final experimental concentration of $0.1,1.0$ and $10.0 \mu \mathrm{mol}^{\mathrm{L} \mathrm{L}^{-1}}$. The flasks were maintained under $110 \mu \mathrm{mol}$ photon $\cdot \mathrm{m}^{-2} \cdot \mathrm{s}^{-1}$ during 2 minutes, when photosynthetic parameters $\left(\Phi_{M}^{\prime}\right.$, ETR and $\Phi_{\mathrm{M}}$ ) were measured.

Fluorescence measurements: We investigated changes on chlorophyll a fluorescence signals with a miniportable PAM fluorometer (mini-PAM, Walz, Effeltrich, Germany) equipped with a halogen lamp to provide actinic light and a leaf-clip holder with a light sensor to monitor incident photosynthetically active radiation (PAR). The PAM system used in this study was originally designed to measure fluorescence in leaves that usually exhibit a strong signal due to their high chlorophyll concentration. For PAM fluorometer measurements, low chlorophyll concentrations can be problematic. For this reason, we concentrated algal cells on a small surface (glass fiber filters S\&S GFA) in order to obtain reliable fluorescence records (Dorigo and Leboulanger, 2001). The concentration was performed by filtration of the 
cells under low pressure $(<30 \mathrm{cmHg})$ to avoid additional stress (Juneau et al., 2002). Filters were then placed for 10s over a paper dampened in WC medium to prevent osmotic stress and cell dessication. The dampened filter was cut into two pieces that were gently wrapped in a thin layer of a PVC film. One piece was immediately placed in the leaf-clip holder at a distance of $7 \mathrm{~mm}$ from the fiberoptic light source in ambient light conditions for measurement of $\Phi^{\prime}{ }_{M}$ and ETR. We measured the photosynthetic performance under increasing actinic irradiance (9 PAR intensities between 0 and 900 $\mu$ mol photons $\cdot \mathrm{m}^{-2} \cdot \mathrm{s}^{-1}$ ). Each PAR lasted 30s and, after the recording of $F^{\prime}$, a saturation pulse $\left(0.8 \mathrm{~s}\right.$ at $6.000 \mu \mathrm{mol} \cdot \mathrm{m}^{-2}$. $\mathrm{s}^{-1}$ ) was applied to determine $\mathrm{F}_{\mathrm{m}}$. The $\phi_{\mathrm{M}}{ }_{\mathrm{M}}$ was then calculated at those 9 light levels and the relative PSII electron transport rate (ETR) was calculated as $\Phi_{M}^{\prime} \cdot$ PAR $\cdot 0.5$.

The other half of filter was maintained in fully dark conditions for 20 minutes, when the potential quantum yield $\left(\Phi_{M}\right)$ was measured. With this parameter, the relative response $(R)$ to the treatments was calculated as a percentage of inhibition as:

$$
\mathrm{R}=\left(r_{0}-r / r_{0}\right) \cdot 100
$$

where $r_{0}$ is the measured response of non-treated algae taken as a control and $r$ is the response of treated algae.

Statistical methods: Since $\Phi_{M}^{\prime}$ values are strongly related to ETR, we performed statistical analyses just on the latter. The effect of DCMU on the electron transport rate between PSII and PSI was analyzed using nonlinear mixed effects modelling, permitting to compare different sections $\left(\alpha, \mathrm{ETR}_{\max }\right.$ and $\left.\beta\right)$ of the obtained curves (for details see Figueredo et al., 2007). The effect of DCMU on the potential quantum yield $\left(\Phi_{M}\right)$ for dark-adapted filters was analyzed statistically by a KruskalWallis test, given that no homogeneity was observed in the variances of these data (Brown-Forsythe test). When significant differences were observed, a Tukey test was applied to verify the differences among control and treatments.

\section{RESULTS}

There were evident inhibitory effects of DCMU on all parameters measured and PAM fluorometry was able to detect differences among treatments.

For all species, $\Phi_{\text {M }}$ was a sensitive parameter, which was completely inhibited $\left(\Phi^{\prime}{ }_{M}=0\right)$ by DCMU concentration of $10.0 \mu \mathrm{mol} \cdot \mathrm{L}^{-1}$ (Figure 1). The DCMU inhibitory effects were more intense on $T$. lagerheimii and $C$. sphaericum, which had their $\Phi^{\prime}{ }_{M}$ decreased by $1.0 \mu \mathrm{mol} \cdot \mathrm{L}^{-1}$ and were completely inhibited by $10.0 \mu \mathrm{mol} \cdot \mathrm{L}^{-1}$ of DCMU, even at very low light intensity (Figure $1 \mathrm{~A}$ and $\mathrm{B}$ ). P. boryanum was the most resistant species. Concentrations of $1.0 \mu \mathrm{mol} \cdot \mathrm{L}^{-1} \mathrm{did}$ not affect it and $10.0 \mu \mathrm{mol} \cdot \mathrm{L}^{-1}$ reduced its $\Phi_{M}^{\prime}$ records to 0 just for light intensities higher than $350 \mu \mathrm{mol} \cdot \mathrm{m}^{-2} \cdot \mathrm{s}^{-1}$ (Figure 1C). The trends described above were statistically confirmed by ETR data, which are related to the $\Phi_{M}^{\prime}$ values.
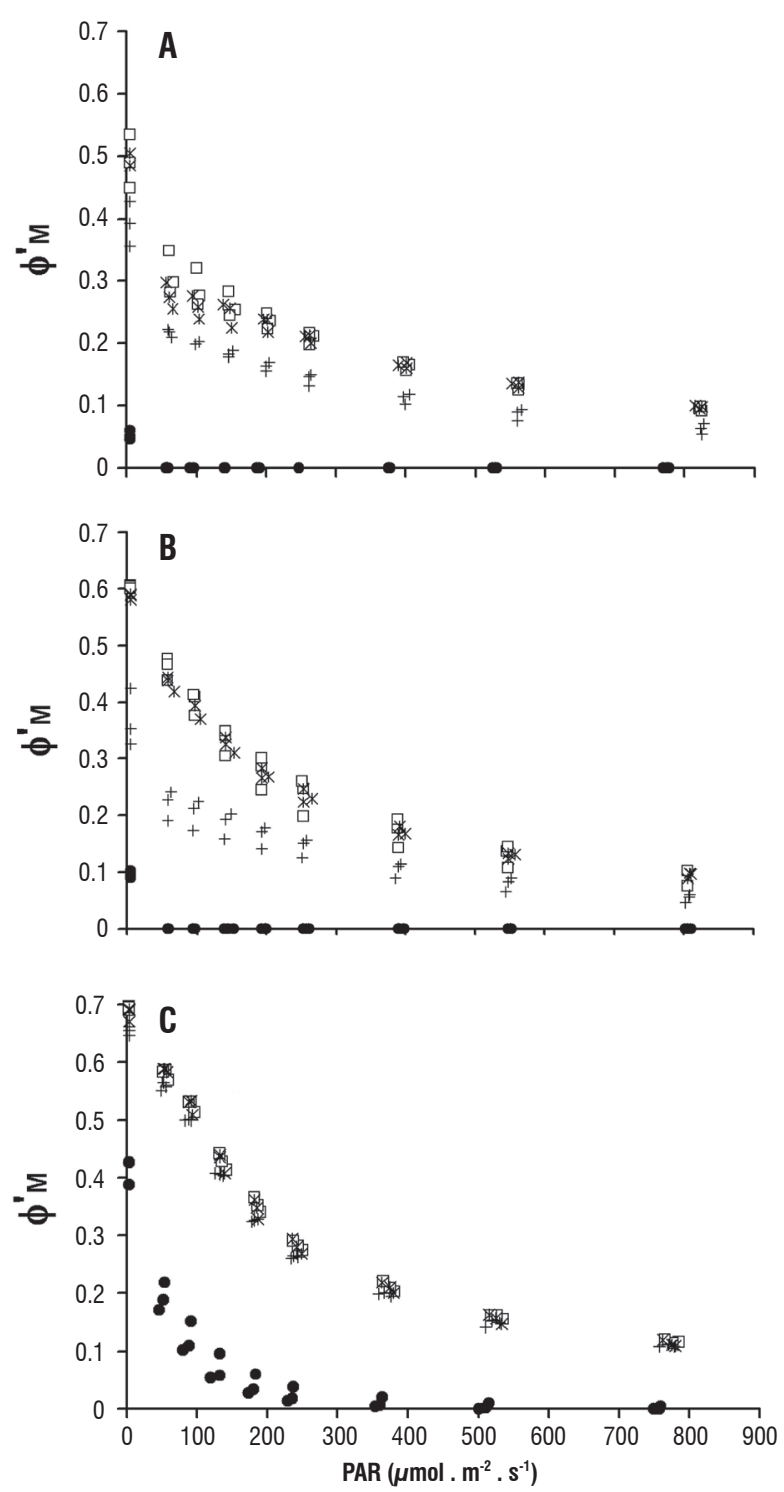
$\square \mathrm{C}$
* $0,1 \mu \mathrm{Mol} / \mathrm{L}$
$+1,0 \mu \mathrm{Mol} / \mathrm{L}$
- $10 \mu \mathrm{Mol} / \mathrm{L}$

Figure 1 - Effective quantum yield curves of control (C, with no DCMU addition) and treatments at different concentrations of DCMU $(0.1,1.0$ and $\left.10.0 \mu \mathrm{mol} \cdot \mathrm{L}^{-1}\right) . A=$ Tetrallanthos largeheimii, $\mathrm{B}=$ Coelastrum sphaericum, $\mathrm{C}=$ Pediastrum boryanum. 
ETR saturation curves, in response to increasing DCMU concentrations, showed very similar trends for Tetrallantos lagerheimii and Coelastrum sphaericum (Figure 2). For both species, a DCMU concentration of $0.1 \mu \mathrm{mol} \cdot \mathrm{L}^{-1}$ did not show any inhibition and no differences were observed among treatment and control parameters (Figure $2 \mathrm{~A}$ and $\mathrm{B}$, Tables 1 and 2). When the two species were submitted to higher DCMU concentration $\left(1.0 \mu \mathrm{mol} \cdot \mathrm{L}^{-1}\right)$, statistically significant differences of $\alpha$ and ETR maximum relative to the control were detected (Tables 1 and 2). Under this DCMU concentration the ETR curve exhibited a lower plateau with an inhibitory effect of ca. 40\% (Figure $2 \mathrm{~A}$ and B). Furthermore, ETR saturation was observed at lower light levels for this treatment (ca. $300 \mu \mathrm{mol}$ photon $\cdot \mathrm{m}^{-2} \cdot \mathrm{s}^{-1}$ ) when compared to the control (ca. $500 \mu \mathrm{mol}$ photon $\cdot \mathrm{m}^{-2} \cdot \mathrm{s}^{-1}$ ) (Figure $2 \mathrm{~A}$ and B). DCMU concentrations of $10.0 \mu \mathrm{mol} \cdot \mathrm{L}^{-1}$ completely blocked the electron flux among PSII and PSI in both T. lagerheimii and C. sphaericum (Figure $2 \mathrm{~A}$ and $\mathrm{B}$, Tables 1 and 2 ).

Table 1 - Response of Tetrallantos largeheimii to the addition of different concentrations of DCMU. The significance of treatment effects was assessed using likelihood ratio tests (Global Test) and t-test comparisons between treatments and control. Units as follows: ETR $\left(\mu \mathrm{mol}\right.$ electrons $\left.\cdot \mathrm{m}^{-2} \cdot \mathrm{s}^{-1}\right) ; \alpha$ ( $\mu \mathrm{mol}$ electrons per $\mu$ mol PAR photons).

\begin{tabular}{ccccc}
\hline Treatment & ETRmax & P-value & $\alpha$ & P-value \\
\hline C & 33.5 & & 0.15 & \\
0.1 & 31.6 & 0.16 & 0.14 & 0.07 \\
1.0 & 22.1 & $<0.0001 \mathrm{a}$ & 0.11 & $<0.0001 \mathrm{a}$ \\
10.0 & 0 & $<0.0001 \mathrm{a}$ & 0 & $<0.0001 \mathrm{a}$ \\
\hline
\end{tabular}

${ }^{a}$ Significant differences at $\mathrm{P}<0.05$ (Global test and t-test).

Table 2 - Response of Coelastrum sphaericum to the addition of different concentrations of DCMU. The significance of treatment effects was assessed using likelihood ratio tests (Global Test) and t-test comparisons between treatments and control. Units as follows: ETR $\left(\mu \mathrm{mol}\right.$ electrons $\left.\cdot \mathrm{m}^{-2} \cdot \mathrm{s}^{-1}\right) ; \alpha$ ( $\mu$ mol electrons per $\mu$ mol PAR photons).

\begin{tabular}{ccccc}
\hline Treatment & ETRmax & p-value & $\alpha$ & p-value \\
\hline C & 30.4 & & 0.22 & \\
0.1 & 29.9 & 0.82 & 0.21 & 0.17 \\
1.0 & 18.5 & $<0.0001 \mathrm{a}$ & 0.12 & $<0.0001 \mathrm{a}$ \\
10.0 & 0 & $<0.0001 \mathrm{a}$ & 0 & $<0.0001 \mathrm{a}$ \\
\hline
\end{tabular}

a Significant differences at $\mathrm{P}<0.05$ (Global test and t-test).

Pediastrum boryanum was clearly the most resistant species to the herbicide DCMU. For this species, $\alpha$ values were never different between treatments and control. Furthermore, this chlorophyte was not affected by DCMU concentrations of $0.1 \mu \mathrm{mol} \cdot \mathrm{L}^{-1}$, which did not produce ETR values statistically different from the control, with no herbicide (Figure 2C, Table 3). Difference between the control and the $1.0 \mu \mathrm{mol} \cdot \mathrm{L}^{-1}$ treatment were significant for $\operatorname{ETR}_{\max }$ (Table 3), but the inhibitory effect was small (ca. 10\%). In the control and the 0.1 and $1.0 \mu \mathrm{mol} \cdot \mathrm{L}^{-1}$ DCMU treatments, ETR saturation occurred at light levels higher than $350 \mu \mathrm{mol} \cdot$ photon $\cdot \mathrm{m}^{-2} \cdot \mathrm{s}^{-1}$ (Figure $2 \mathrm{C}$ ). Different from the other species, $P$. boryanum was able to maintain electron transport among photosystems even when submitted to higher DCMU concentration $\left(10.0 \mu \mathrm{mol} \cdot \mathrm{L}^{-1}\right)$. At this concentration, the electron flux was completely blocked just when light levels were higher than $500 \mu \mathrm{mol} \cdot$ photon $\cdot \mathrm{m}^{-2} \cdot \mathrm{s}^{-1}$ (Figure 2C).
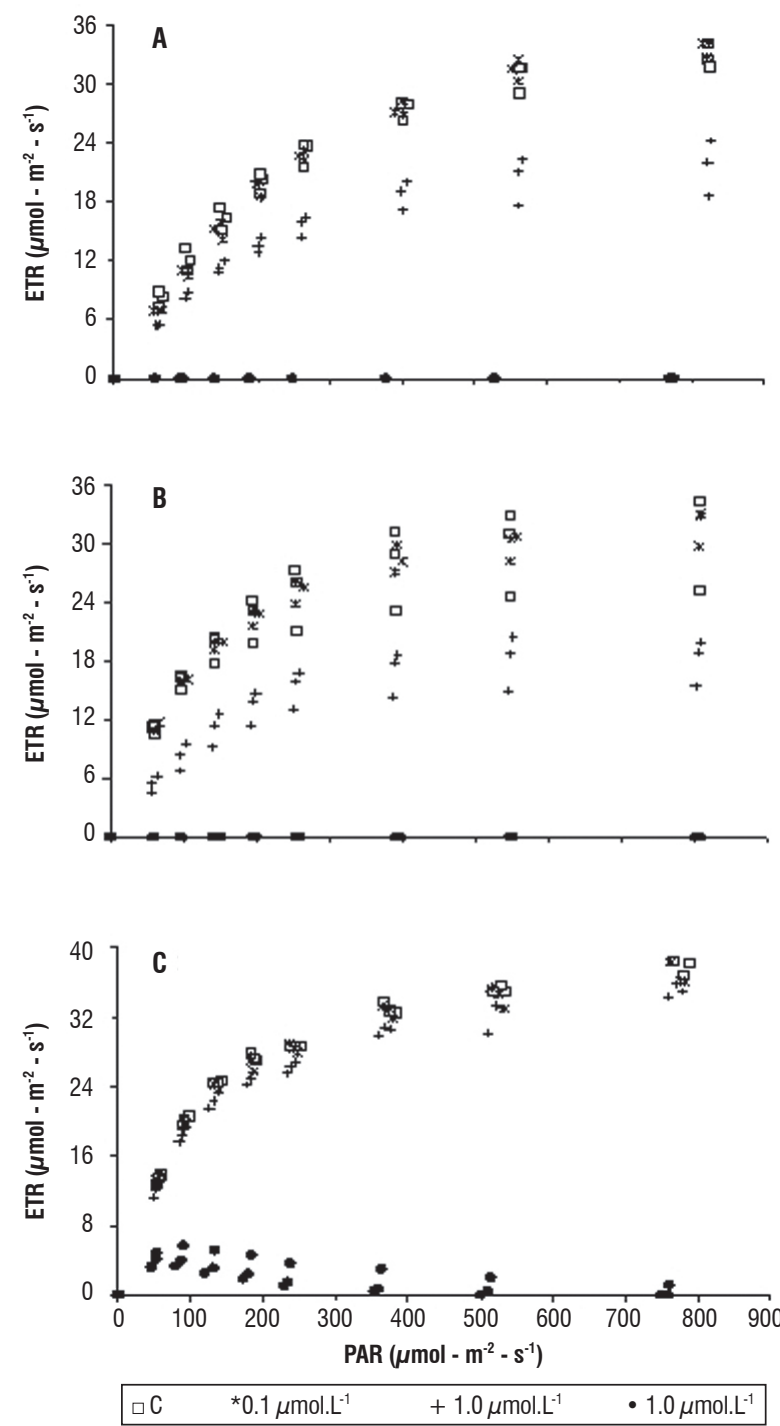

Figure 2 - Electron transport rate curves of control (C, with no DCMU addition) and treatments at different concentrations of DCMU $(0.1,1.0$ and $\left.10.0 \mu \mathrm{mol} \cdot \mathrm{L}^{-1}\right)$. A = Tetrallanthos largeheimii, $\mathrm{B}=$ Coelastrum sphaericum, $\mathrm{C}=$ Pediastrum boryanum. 
Table 3 - Response of Pediastrum boryanum to the addition of different concentrations of DCMU. The significance of treatment effects was assessed using likelihood ratio tests (Global Test) and t-test comparisons between treatments and control. Units as follows: ETR $\left(\mu \mathrm{mol}\right.$ electrons $\left.\cdot \mathrm{m}^{-2} \cdot \mathrm{s}^{-1}\right) ; \beta$ ( $\mu$ mol electrons per $\mu$ mol PAR photons). Since. $\alpha$ values ( $\mu$ mol electrons per $\mu \mathrm{mol}$ PAR photons) were not different among treatments and control, they were not represented in this table.

\begin{tabular}{ccccc}
\hline Treatment & ETRmax & P-value & $\beta$ & P-value \\
\hline C & 34.8 & & 0 & \\
0.1 & 34.0 & 0.23 & 0 & \\
1.0 & 31.5 & $<0.0001 \mathrm{a}$ & 0 & \\
10.0 & 3.9 & $<0.0001 \mathrm{a}$ & -0.0055 & $<0.0001 \mathrm{a}$ \\
\hline
\end{tabular}

a Significant differences at $\mathrm{P}<0.05$ (Global test and t-test).

The potential quantum yield $\left(\Phi_{\mathrm{M}}\right)$ responses to increasing DCMU concentrations were similar among the three chlorophytes (Figure 3). This parameter showed no changes at a DCMU concentration of $0.1 \mu \mathrm{mol} \cdot \mathrm{L}^{-1}$. On the other hand, concentrations higher than $1.0 \mu \mathrm{mol}$. $\mathrm{L}^{-1}$ resulted in a statistically significant inhibition of $\Phi_{\mathrm{M}}$. The effects were significantly higher for DCMU concentration of $10.0 \mu \mathrm{mol} \cdot \mathrm{L}^{-1}$. Although these general trends were similar for all species, absolute values were always lower for $T$. lagerheimii and comparable absolute values of $\Phi_{\mathrm{M}}$ in the control and treatments were found just for $C$. sphaericum and $P$. boryanum. Furthermore, T. largeheimii was more strongly inhibited by DCMU (Table 4). While both $C$. sphaericum and $P$. boryanum had a $\Phi_{\mathrm{M}}$ decrease of 6 and $17 \%$, respectively for $\mathrm{DCMU}$ concentrations of 1.0 and $10.0 \mu \mathrm{mol} \cdot \mathrm{L}^{-1}, \mathrm{~T}$. lagerheimii was more sensitive and showed reductions of 12.5 and $36 \%$ (Table 4).

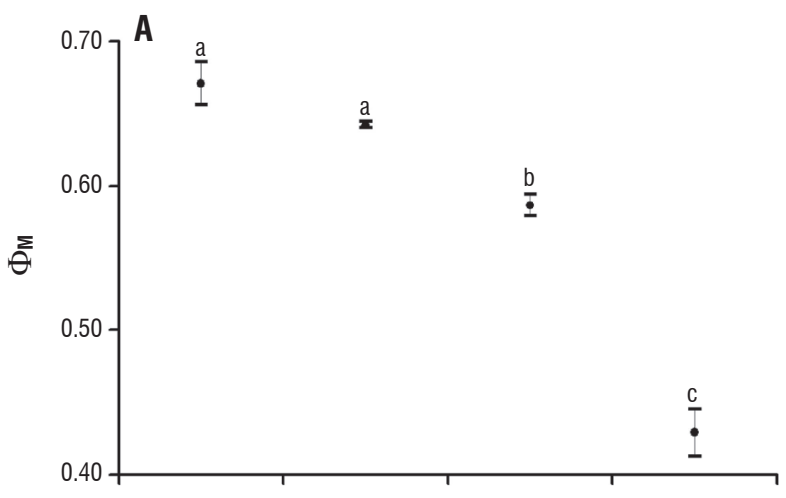

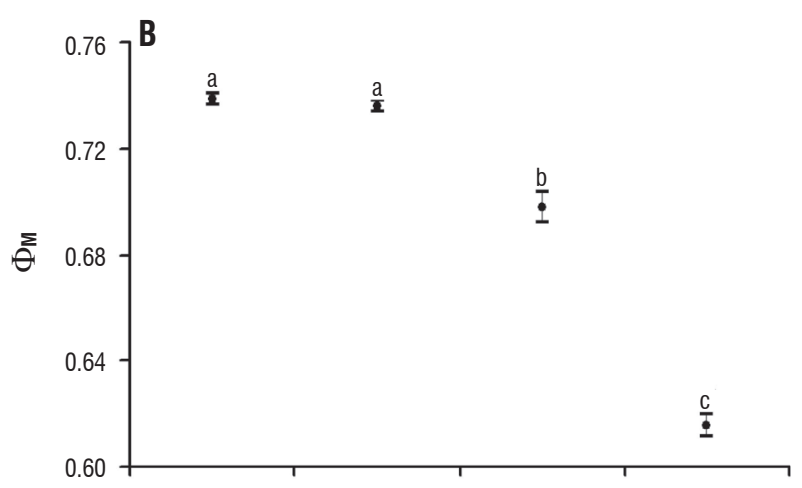

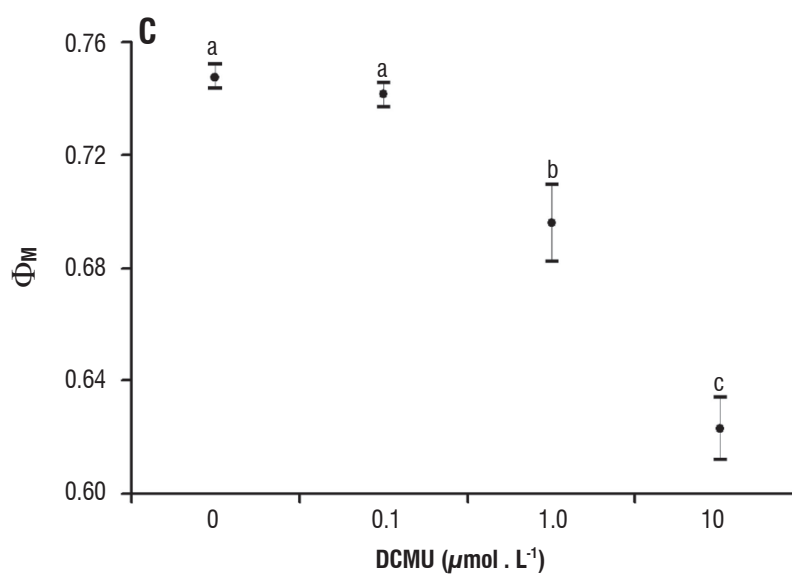

Figure 3 - Potential quantum yield (mean and standard deviation) of control (C, with no DCMU addition) and treatments at different concentrations of $\operatorname{DCMU}\left(0.1,1.0\right.$ and $\left.10.0 \mu \mathrm{mol} \cdot \mathrm{L}^{-1}\right)$.

Small letters in each graphic correspond to the result of the Tukey test, where the same letter indicates no significative differences $(p>0.05)$ and differentletters indicates significative differences $(\mathrm{p}<0.05)$. $\mathrm{A}=$ Tetrallanthos largeheimii, $\mathrm{B}=$ Coelastrum sphaericum, $\mathrm{C}=$ Pediastrum boryanum.

Table 4 - Percent inhibition of the potential quantum yield (means (standard deviation) of R-values).

\begin{tabular}{cccc}
\hline DCMU ( $\boldsymbol{\mu m o l}$. L-1) & T. lagerheimii & C. sphaericum & P. boryanum \\
\hline 0.1 & $4.19(2.19)$ & $0.36(0.51)$ & $0.84(1.11)$ \\
1.0 & $12.50(1.84)$ a & $5.50(0.89)$ a & $6.95(2.19)$ a \\
10.0 & $36.05(1.16)$ a & $16.65(0.32)$ a & $16.68(1.18)$ a \\
\hline
\end{tabular}

a Significant differences at $\mathrm{P}<0.05$ (Kruskal-Wallis test). 


\section{DISCUSSION}

The results indicated that the method was able to produce reliable fluorescence measurements of the photosynthetic capacity of phytoplanktonic species. The patterns observed in the $\Phi^{\prime}{ }_{M}$ and ETR responses were very similar to those described in the literature for natural leaves leading to the conclusion that filters containing microalgal cells could be used as "artificial leaves". Results were consistent, since the recorded values were very similar in all triplicates for each treatment. Differences among treatments and control could be detected and, as expected, increased at higher DCMU concentrations. Higher concentrations of DCMU (1.0 and 10.0 $\left.\mu \mathrm{mol} \cdot \mathrm{L}^{-1}\right)$ affected PSIl in all three species, since ETR values were much lower at these two concentrations than in the control. Thus, PAM fluorometry appears to be an efficient noninvasive tool to detect changes in photosynthetic activity of microphytoplankton cultures and may be a trustworthy way to study phytoplankton responses to environmental conditions or to stressing factors. Juneau and Popovic (1999), for example, used PAM fluorimetry to study toxic effects of different agents on phytoplankton photosynthesis. However, we recommend using this methodology just for unialgal cultures because photosynhetic responses showed different patterns and intensities even for related genera. Villareal (2004) also found different fluorescence responses in two diatoms genera (Ethmodiscus and Phaeodactylum Bohin) suggesting that these results emerged from differences in their taxonomy or in their light adaptation history. In another study, Macedo et al. (2008) showed that the toxicity of the herbicide bentazon on phytoplankton was also species-specific. Although field samples responses were not the scope of this study, we reinforce the necessity to carefully evaluate field fluorescence data due the complexe composition of the phytoplankton community in natural systems and the consequent different outcomes from its individual components.

The inhibitory effects were evaluated throughout the measured parameters as a relative decrease in photosynthesis and showed that different species of the order Chlorococcales (Chlorophyta) were differently sensitive to DCMU. Podola and Melkonian (2003) also reported that a methanol-induced inhibition of photosynthesis was clearly not the same among different algal species or strains. Juneau et al. $(2001,2002)$ observed that the sensitivity of algal species to mercury, cupper and to the herbicide metolachlor also varied largely, according to the used species and toxicants. These authors suggested that morphological features might affect the algal sensibility to chemical substances. In our study, variation in morphology could explain, at least partially, the different responses in the ETR curves recorded. Although all species studied have typically a colonial organization in nature, just $P$. boryanum maintained its colonial form in our culture conditions, while $C$. sphaericum and $T$. lagerheimii grew mainly unicellular. The relative cell surface exposed to DCMU was lower in $P$. boryanum, once the cells of this species are strongly bound into colonies. This fact was confirmed by the different surface:volume ratios of the studied species. While $P$. boryanum had a $\mathrm{S}: \mathrm{V}$ ratio of $0.3( \pm 0.1), C$. sphaericum and $T$. lagerheimii showed S:V ratios of $1.3( \pm 0.3)$ and $1.7( \pm 0.5)$, respectively. Therefore, considering just this morphological aspect, the relative exposition to toxicants could be about 5 times lower in $P$. boryanum than in the other two chlorophytes. However, morphology could just partially explain the results on potential quantum yield. This parameter showed the same trend of sensivity for $P$. boryanum and $C$. sphaericum, both being more resistant than $T$. lagerheimii. Since $T$. largeheimii presented the highest S:V ratio, we could expect its lower resistance, however similar trends of sensitivity for $P$. boryanum and $C$. sphaericum appear not be related to the morphological characteristics of these two species. Thus, beyond morphology, probably physiology and historic aspects of the cultures or of the natural populations may also affect fluorescence results. Diverse responses in fluorescence among species or among higher taxonomical groups were observed in other studies. Alpine and Cloern (1985) indicated, for example, that changes in light conditions of the growth environment (light life history) could affect the physiology and, hence, the fluorescence yield of the phytoplankton.

In conclusion, by using mini-PAM fluorometry on microalgae concentrated on glass fiber filters we were able to assess PSII inhibition and effectively measure the sensitivity of phytoplanktonic species to the inhibitory effect of DCMU. However to attain accurate results some precautions should be taken, as, for example, experiments should be performed on the same species growing under similar conditions. Absolute values obtained for different species are difficult to be evaluated or compared. The use of fluorescence measurements for the acquisition of photosynthesis absolute rates under different growth conditions are not a consensus in literature (Walker et al., 1983; Genty et al., 1989; Silva et al., 
1998). In fact, even for the same species, cell age and light intensity during life cycle may influence the photochemical metabolism of the cultures (Heinze et al., 1996, Nash and Quayle, 2007). However, we showed that it is possible to compare the response to treatments as relative values of just one species, with excellent results. Furthermore, when using PAM fluorometry the choice of the best parameter to describe the response is also important. Juneau et al. $(2001,2002)$ considered the operational PSII quantum yield $\left(\Phi^{\prime}{ }_{\mathrm{M}}\right)$ as a useful parameter for plant and phytoplankton bioassays. From our results, it appears that $\Phi^{\prime}{ }_{M}$ and ETR were both sensitive parameters for measuring the toxic effect of DCMU on algae. The potential quantum yield $\left(\Phi_{\mathrm{M}}\right)$ could also be used but with lower sensivity, once $\Phi_{\mathrm{M}}$ values suffered less reduction and very low values, as the 0 values recorded for $\Phi_{M}^{\prime}$, were not observed.

Acknowledgements: we wish to thank D.F. Bird for the development of the statistical non-linear method used to analyze the ETR curves. This study was supported by a fellowship to C.C.F. from CAPES (Coordenação de Aperfeiçoamento do Pessoal Docente, Brazil).

\section{REFERENCES}

Alpine AE, Cloern JE (1985) Differences in in vivo fluorescence yield between three phytoplankton size classes. J. Plankton Res. 7:381-390.

Dorigo U, Leboulanger C (2001) A pulse-amplitude modulated fluorescencebased method for assessing the effects of photosystem II herbicides on freshwater periphyton. J. appl. Phycol. 13:509-515.

Figueredo CC, Giani A, Bird DF (2007) Does allelopathy contribute to Cylindrospermopsis raciborskii (cyanobacteria) bloom occurrence and geographic expansion? J. Phycol. 43:256-265.

Genty B, Briantais JM, Baker NR (1989) The relationship between the quantum yield of photosynthetic electron transport and quenching of chlorophyll fluorescence. Biochim. Biophys. Acta 990:87-92.

Guillard RR, Lorenzen CJ (1972) Yellow-green algae with chlorophyllidae C1,2. J. Phycol. 8:10-14.

Heinze I, Dau H, Senger H (1996) The relation between the photochemical yield and variable fluorescence of photosystem II in the green alga Scenedesmus obliquus. J. Photochem. Photobiol. B Biol. 32:89-95.

Juneau P, Popovic R (1999) Evidence for the rapid phytotoxicity and environmental stress evaluation using the PAM fluorometric method: importance and future application. Ecotoxicology 8:449-455.
Juneau P, Dewez D, Matsui S, Kim SG, Popovic R (2001) Evaluation of different algal species sensitivity to mercury and metolachlor by PAM-fluorometry. Chemosphere 45:589-598.

Juneau P, El Berdey A, Popovic R (2002) PAM-fluorometry in the determination of the sensitivity of Chlorella vulgaris, Selenastrum capricornutum and Chlamydomonas reinhardtii to copper. Arch. Environ. Contam. Toxicol. 42:155-164.

Krause GH, Weis E (1991) Chlorophyll fluorescence and photosynthesis: the basics. Annu. Rev. Plant Physiol. Plant. Mol. Biol. 42:313-349.

Lu C, Vonshak A (1999) Photoinhibition in outdoor Spirulina platensis cultures assessed by polyphasic chlorophyll fluorescence transients. J. Appl. Phycol. 11:355-359.

Macedo RS, Lombardi AT, Omachi CY, Rörig LR (2008) Effects of the herbicide bentazon on growth and photosystem II maximum quantum yield of the marine diatom Skeletonema costatum. Toxicol. In Vitro. 22:716-722.

Nash SMB, Quayle PA (2007) Biomaterial culture conditions impacting the performance of a PAM fluorometry based aquatic phytotoxicity assay. Biosens. Bioelectron. 23:276-280.

Parkhill JP, Maillet G, Cullen JJ (2001) Fluorescence-based maximal quantum yield for PSII as a diagnostic of nutrients stress. J. Phycol. 37:517-529.

Podola B, Melkonian M (2003) A long-term operating algal biosensor for the rapid detection of volatile toxic compounds. J. Appl. Phycol. 15:415-424.

Rott E (1981) Some results from phytoplankton counting intercalibrations. Schweiz. Z. Hydrol. 43:34-62.

Schreiber U (1986) Detection of rapid induction kinetics with a new type of high- frequence modulated chlorophyll fluorometer. Photosynth. Res. 9:261272.

Schreiber U, Bilger W (1987) Rapid assessment of stress effects on plant leaves by chlorophyll fluorescence measurements. In: Tenhunen J, Catarino FM, Lange OL, Oechel WC (eds), Plant Response Stress, pp. 27-56. SpringerVerlag, Berlin.

Schreiber U, Hormann H, Neubauer C, Klughammer C (1995) Assessment of photosystem II photochemical quantum yield by chlorophyll fluorescence quenching analysis. Aust. J. Plant Physiol. 22:209-220.

Schreiber U, Gademann R, Ralph PJ, Larkum, AWD (1997) Assessment of photosynthetic performance of Prochloron in Lissoclinum patella in hospite by chlorophyll fluorescence measurements. Plant Cell Physiol. 38:945-951.

Schreiber U (2003) In vivo chlorophyll fluorescence: assessment and analysis of photosynthesis function. In: Larcher W (ed), Physiological plant ecology: ecophysiology and stress physiology of functional groups. $513 \mathrm{p}$. Springer, Berlin.

Silva J, Santos R, Serôdio J, Melo RA (1998) Light response curves for Gelidium sesquipedale from different depths, determined by two methods: $\mathrm{O}_{2}$ evolution and chlorophyll fluorescence. J. Appl. Phycol. 10:295-301.

Villareal TA (2004) Single-cell pulse amplitude modulation fluorescence measurements of the giant diatom Ethmodiscus (Bacillariophyceae). J. Phycol. 40:1052-1061.

Walker DA, Sivak MN, Prinsley RT, Cheeseborough JK (1983) Simultaneous measurements of oscillations in oxygen evolution and chlorophyll fluorescence in leaf pieces. Plant Physiol. 73:542-549.

Wilhelm C, Becker A, Toepel J, Vieler A, Rautenberger R (2004) Photophysiology and primary production of phytoplankton in freshwater. Physiol. Plant 120:347-357. 